\title{
Det kristne næstekærlighedsbud som etisk anti-etik
}

\author{
En teologisk-psykoanalytisk udveksling \\ Postdoc., Ph.d. \\ Mads Peter Karlsen
}

\begin{abstract}
The twofold aim of this article is to demonstrate (1) that a more constructive and mutually productive relationship is possible between theology and psychoanalysis, and doing this arguing (2) that psychoanalysis can assist theology understand the injunction of neighbour love as a form of ethical anti-ethics while theology can assist psychoanalysis maintain the ethical insight that there is something about human existence that is beyond the pleasure principle, something that cannot be reduced to a matter of pure survival and life sustainment, and that this constitutes a challenge for ethics. The article's first three sections can be divided into two main parts. The first part (section 2) accounts for the criticism of the Christian variation of the injunction of neighbour love that Freud presents in Civilization and Its Discontents, and examines the background for this critique. The second part (section 3-4) encircles the concept of the neighbour as the hub of a form of ethical anti-ethics through a reading of some key passages from Jacques Lacan's famous Seminar VII on psychoanalytic ethics and Søren Kierkegaard's Works of Love. The article last section (section 5) provides a brief concluding summary.
\end{abstract}

Key words: Neighbour-love - Death Drive - Enjoyment - Ethics - Theology - Psychoanalysis - Freud - Lacan - Kierkegaard

\section{Indledning: Teologi og psykoanalyse?}

Psykoanalysen har gennem det mest af sin historie på baggrund af Freuds religionskritisk været præget af en særdeles skeptisk, hvis ikke ligefrem fjendtlig, indstilling over for religion og teologi. Måske netop derfor har teologien på sin side været relativt forbeholden over for psykoanalysen. Psykoanalysen har siden 1970erne nok fundet en vis klangbund som litterær metode i de eksegetiske fag og som terapeutisk redskab i poimenikken, men med enkelte vigtige undtagelser - så som Paul Tillich, Paul Ricoeur og Eugen Drewermann - er der indtil for nyligt kun blevet gjort ganske få forsøg fra systematisk teologisk side på at indlede en dialog med psykoanalysen. Den systematiske teologi anerkender naturligvis, at enhver tidssvarende teologi må være 
sig bevidst om og tage ved lære af psykoanalysens religionskritiske indsigter, men spørgsmålet er om også et mere gensidigt og konstruktivt forhold mellem den systematiske teologi og psykoanalysen er muligt. ${ }^{1}$

De mange og markante forskelle til trods er der en række åbenlyse anknytningspunkter mellem teologi og psykoanalyse. Et af dem er spørgsmålet om, hvad kærlighed er, som er et absolut centralt anliggende inden for begge traditioner. Der er således næppe tvivl om, at såvel kristendommen som psykoanalysen hver især på en fuldstændig afgørende måde har været med til at præge den vestlige kulturkreds' opfattelse af kærlighed. Dette rejser dog samtidigt spørgsmålet om forholdet mellem en teologisk og en psykoanalytisk kærlighedsopfattelse, som af flere grunde er et både komplekst og flertydigt spørgsmål. Ikke kun fordi Freuds teorier om det menneskelige kærlighedsliv i høj grad blev udviklet i opposition til en kristent farvet seksualmoral, men også fordi kærligheden er blevet tænkt meget forskelligt inden for begge disse traditioner, og fordi kærlighed i sig selv er et mangefacetteret fænomen. Kærlighed kan således ifølge tbåde eologien og psykoanalysen tage mange forskellige skikkelser: erotisk kærlighed, venskab, filantropi, egenkærlighed, kærlighed til Gud, næstekærlighed, for at nævne nogle stykker.

Selvom det utvivlsomt kunne være interessant, er mit anliggende i det følgende dog hverken at udfolde en egentlig fænomenologi over kærlighedens former, sådan som de fremstilles i teologien og psykoanalysen, eller at sammenligne dem. ${ }^{2}$ Jeg vil i stedet mere beskedent nøjes med at fokusere på kærligheden i én af dens former, nemlig næstekærlighed og mere præcist den kristne opfattelse af næstekærlighed, samt på den Freudianske psykoanalyses kritiske perspektiv derpå. Det er således spørgsmålet om kærlighedens rolle i etikken snarere end kærligheden som sådan, der er i fokus. Min behandling af dette

1. Noget tyder på det, se fx James DiCenso, The Other Freud: Religion, Culture \& Psychoanalysis (London: Routledge 1999); Erich L. Santner, The Psychotheology of Everyday Life: Reflections on Freud and Rosenzweig (Chicago: University of Chicago Press 2001); Slavoj Žižek, Erich L. Santner \& Kenneth Reinhard, The Neighbor: Three Inquiries in Political Theology (Chicago: University of Chicago Press 2005); Thomas Dalzell, "Towards a Psychoanalytic Theology of Original Sin”, IThQ 71 (2006), 89-112; Erin Felicia Labbie, Lacan's Medievalism (Minneapolis: University of Minnesota Press 2006); Clayton Crockett, Interstices of the Sublime: Theology and Psychoanalytic Theory (New York: Fordham University Press 2007); Marcus Pound, Theology, Psychoanalysis and Trauma (London: SCM Press 2007); Kenneth Reinhard, "There is Something of One (God): Lacan and Political Theology", Political Theology 11 (2010), 43-60

2. Se i stedet Werner Jeanrond, Theology of Love (London: T\&T Clark, 2010) og Ole Andkjær Olsen \& Simo Køppe, Psykoanalysen efter Freud 1-2 (København: Gyldendal 1996). 
emne vil imidlertid være styret af et dobbelt spørgsmål. Ikke kun: Hvordan kan psykoanalysen belyse det kristne næstekærlighedsbud? Men også: Hvordan kan det kristne næstekærlighedsbud belyse psykoanalysen? Pointen er altså at forsøge i praksis at demonstrere min indledende påstand om, at et mere gensidigt og konstruktivt forhold mellem den systematiske teologi og psykoanalysen er muligt. Det vil jeg gøre med afsæt i tre teser.

Jeg mener for det første, (1) at psykoanalysen kan være med til at minde teologien om det radikale ved tanken om næstekærlighed, og dermed være med til at problematisere den karakter af selvfølgelighed som talen om næstekærlighed tenderer mod at have i dag. ${ }^{3}$ For det andet mener jeg, (2) at psykoanalysen kan være med til at vise, hvorfor næstekærlighedsbuddet ikke kan danne grund for en etik i traditionel forstand, men tværtimod udgør en slags anti-etik om end i en vis forstand en etisk anti-etik. Sidst, men ikke mindst, mener jeg, (3) at teologien med næstekærlighedsbuddet kan være med til at holde psykoanalysen fast på en af dens egne centrale etiske indsigter, nemlig at der er noget ved den menneskelige eksistens, der er hinsides lystprincippet; eller anderledes formuleret: at menneskelivet ikke kan reduceres til en i sidste ende egoistisk selvopretholdelseskamp. Disse tre teser vil jeg udfolde og underbygge i det følgende.

Artiklens tre første afsnit kan inddeles i to hoveddele. I første del (afsnit 2) præsenteres den kritik af det kristne næstekærlighedsbud, som Freud fremsætter i Kulturens byrde, samt en afklaring af baggrunden for denne kritik. I artiklens anden del (afsnit 3-4) indkredses næstebegrebet som omdrejningspunkt for en etisk anti-etik gennem en læsning af en række centrale passager fra Jacques Lacans Seminar VII om psykoanalysens etik og Søren Kierkegaards Kjerlighedens Gjerninger. Artiklens sidste afsnit (afsnit 5) udgør en kort afsluttende sammenfatning.

\section{Freuds kritik af det kristne næstekærlighedsbud}

I sin bog Kulturens byrde fra 1930 kritiserer Freud næstekærlighedsbuddet for mindst fire forhold. (1) Buddet er for det første psykologisk urealistisk, fordi menneskets kærlighed ifølge Freud i sidste ende altid er selvkærlighed. For Freud findes der kun én slags kærlighed, der dog kan tage forskellige former; han kalder denne kærlighed for

3. Se Mads Peter Karlsen, "Næstekærlighed: Krarup med Lacan”, Dansk Teologisk Tidsskrift 75 (2012), 275-286. 
“seksuel kærlighed", "Eros” eller "libido" alt efter synsvinklen (økonomisk, dynamisk, topologisk) og perioden i forfatterskabet. ${ }^{4}$ Kærlighed er hos Freud karakteriseret ved, at den, der elsker en anden, selv psykologisk set har fordel af sin kærlighed, og at dette forhold er fundamentalt for kærlighedsrelationer. Det betyder altså, at det elskende subjekt i et kærlighedsforhold ikke går ud over sin selvkærligheds grænse, men blot forskyder denne grænse, så den omfatter andre personer eller grupper, som dette subjekt kan identificere sig med (Freud 1976, 112-113). Kærlighed til andre, hvad enten den har det kønslige forholds, forældrerelationens, venskabets eller det nationale fællesskabs karakter, er i sidste ende (udvidet) kærlighed til sig selv. Anderledes sagt, for Freud er kærlighed, også næstekærlighed, altid selvkærlighed, det vil i psykoanalytiske termer sige narcissistisk. I Kulturens byrde formulerer Freud det således:

Når jeg elsker den anden, må han på en eller anden måde fortjene det [...]. Han fortjener det, hvis han på vigtige områder ligner mig selv så meget, at jeg i ham kan elske mig selv; han fortjener det, hvis han er så meget mere fuldkommen end jeg, at jeg i ham kan elske mit ideal billede af min egen person. ${ }^{5}$

(2) For det andet er næstekærlighedsbuddet ifølge Freud etisk forargeligt, fordi dets universalisme nivellerer vores kærlighed. Men det er ifølge Freud ikke alle, der har fortjent vores kærlighed og slet ikke lige meget af den. Med Freuds ord:

Min kærlighed er noget værdifuldt for mig, som jeg ikke har lov til at kaste i grams [...]. Når jeg elsker den anden, må han [derfor] på en eller anden måde fortjene det. [...] hvis han er mig fremmed og ikke kan tiltrække mig i kraft af nogen som helst selvstændig værdi eller en allerede erhvervet betydning for mit følelsesliv, bliver det vanskeligt for mig at elske ham. Jeg vil oveni købet gøre uret derved, for min kærlighed bliver af alle mine nærmeste betragtet som noget, de har fortrinsret til, og det ville være uretfærdigt over for dem, hvis jeg stillede en fremmed lige med dem (Freud 1999, 59-60).

(3) For det tredje anser Freud næstekærlighedsbuddet, 'det yngste af det kulturelle overjegs bud', som han kalder det, for at være en kilde

4. Se fx Sigmund Freud, "Massepsykologi og jeg-analyse”, i Freud, Metapsykologi II (København: Hans Reitzels Forlag 1976), 103. En anden central tekst for Freuds konception af kærlighed er "Om indføring af begrebet narcissisme" fra 1914.

5. Sigmund Freud, Kulturens byrde (København: Hans Reitzels Forlag 1999), 5960. 
til menneskelig ulykkelighed, fordi det med dets urealiserbare krav er neuroseskabende. Næstekærlighedsbuddet tager ikke hensyn til selvkærlighedens naturlige higen efter tilfredsstillelse, men det fordrer tværtimod en beherskelse af denne drift, som det realistisk set er umuligt at imødekomme. Med udgangspunkt i sin såkaldte anden personlighedsmodel (Det'et, Jeget, Overjeg'et) formulerer Freud det således:

[Næstekærlighedsbuddet] går ud fra, at det er psykologisk muligt for menneskets Jeg at gøre alt, hvad man pålægger det - at Jeg'et er i besiddelse af det uindskrænkede herredømme over sit Det. Dette er en fejltagelse, og heller ikke ved såkaldte normale mennesker lader beherskelsen af Det'et sig udstrække længere end til en vis grænse. Forlanger man mere, gør man den enkelte oprøsk, neurotisk eller ulykkelig (Freud 1999, 93).

(4) For det fjerde kritiserer Freud næstekærlighedsbuddet for at være udtryk for en ikke blot naiv, men falsk antropologi. Buddets implicitte menneskesyn fungerer som en illusion, der dækker over det ubehagelige faktum, at mennesket rummer en grundlæggende aggressiv tilbøjelighed. Næstekærligheden er kort sagt en idealisering af mennesket, som bortlyver dets sande natur. Som Freud skriver:

Bag alt dette [altså næstekærlighedstanken] står det stykke virkelighed, som gerne fornægtes: at mennesket ikke er et blidt, kærlighedstrængende væsen [...], men at det til de drifter, det er udstyret med, også kan regne en god portion aggressionstilbøjelighed (Freud 1999, 61).

På trods af sin kritik anerkender Freud i sin diskussion af næstekærlighedsbuddet samtidigt, at næstekærligheden udgør en form for kærlighed, der adskiller sig fra den seksuelle kærlighed, fordi den, der øver næstekærlighed ikke kan forvente, at han eller hun mødes af genkærlighed, eller at kunne drage fordel af sin kærlighed. Freud har med andre ord blik for, at næstekærligheden er en form for kærlighed, der ser bort fra om den anden har gjort sig fortjent til min kærlighed, fordi han ligner mig, at næstekærligheden er asymmetrisk og uselvisk. Men han afviser den altså som en reel mulighed. Mere præcist: Det kristne næstekærlighedsbud er for Freud ikke blot urealistisk og ufornuftigt, men ligeledes uetisk både i den forstand, at det kan være ødelæggende for det gode liv forstået som det psykisk sunde liv, og den i forstand, at det med sit krav om universalisme kan skabe konflikter i vores relationer til den nære anden. 
Der kan dog argumenteres for, at Freuds kritik ikke er en kritik af næstekærlighedsbuddet i alle dets varianter, og at Freud faktisk er positivt indstillet over for en fortolkning, som ligger tættere på den jødiske traditions betoning af reciprocitet og partikularisme end den kristne traditions betoning af asymmetri og universalisme. ${ }^{6}$ Freud bemærker i øvrigt selv, at: "Ja, hvis dette storslåede bud havde lydt: Du skal elske din næste, således som din næste elsker dig, så havde jeg ikke haft noget at indvende" (Freud 1999, 61). Så meget om Freuds kritik. Lad os nu se lidt nærmere på baggrunden for den.

\section{Dødsdrift og arvesynd}

Bag Freuds afvisning af næstekærlighedsbuddet ligger der - som allerede antydet - en bestemt antropologi. I Freuds optik er fordringen om næstekærlighed ikke blot umulig, fordi enhver kærlighed i sidste instans er selvkærlighed, men også fordi mennesket foruden en tilbøjelighed til (selv)kærlighed som nævnt også er udstyret med 'en god portion aggressionstilbøjelighed'. Eller i den sene Freuds sprogbrug: Foruden kærlighedsdriften er mennesket også bestemt af en dødsdrift. I Kulturens byrde understreger Freud dette, idet han skriver:

Det er tilstedeværelsen af denne aggressionstilbøjelighed [dødsdriften] [...], som forstyrrer vort forhold til Næsten og tvinger kulturen til dens opbud. [...] Til trods for alle sine anstrengelser har denne kulturbestræbelse hidtil ikke opnået synderlig meget (Freud 1999, 62-63).

Selvom Freud til tider udviser en vis optimisme på fornuftens og videnskabens vegne, kan der efter introduktionen af dødsdriftsbegrebet i Hinsides lystprincippet spores en grundlæggende pessimisme i hans skrifter i forhold til menneskets muligheder for en lykkelig tilværelse. Flere Freudfortolkere har således bemærket, at Freuds psykoanalytiske antropologi i kraft af dette begreb om dødsdrift står i nært slægtskab med det menneskesyn, som kommer til udtryk i arvesyndslæren. ${ }^{7}$ I en dansk sammenhæng skriver Kresten Nordentoft eksempelvis i en note i Kierkegaards psykologi følgende:

6. Ernest Wallwork, "Thou Shalt Love Thy Neighbor as Thyself: The Freudian Critique”, JRE 10 (1982), 264-319.

7. Bl.a. sociologerne Will Herberg og David Riesman, der begge i forlængelse af Robert K. Merton beskriver Freuds begreb om dødsdriften som en biologisk variant af arvesyndslæren, samt historikeren Paul A. Robinson. Men man kunne ligeledes nævne Jacob Taubes, ("Religion and the Future of Psychoanalysis", Psychoanalysis 4-5 (1957), 139 og Norman O. Brown, Life Against Death (Middletown: Wesleyan 
Men når Freud fx fremstiller sin teori om dødsinstinktet og den konstitutionelle aggressivitet [...], eller når han afviser troen på menneskets naturlige godhed som en illusion [...], så er det nærliggende at kalde hans psykologi et forsøg på en videnskabelig kortlægning af arvesynden $[\ldots]^{8}$

Der er da også - som Nordentoft antyder - klart belæg hos Freud selv for en sådan sammenligning. For det første kommer Freud med adskillige spredte bemærkninger, der kan understøtte opfattelsen af, at psykoanalysens menneskesyn er analogt med det, der kommer til udtryk i arvesyndslæren. Eksempelvis i Totem og tabu, hvor han pointerer, at "Psykoanalysen bekræfter, hvad de fromme plejer at sige: at vi alle sammen er arge syndere", eller i Kulturens byrde, hvor han omtaler dødsdriften som "menneskets medfødte tilbøjelighed til 'det onde." " For det andet drager Freud selv både i Totem og tabu og i Manden Moses eksplicitte paralleller mellem kristendommens lære om arvesynden og psykoanalysens 'videnskabelige myte' om mordet på urfaderen. Freud fremfører således - i hvert fald fra og med Totem og tabu (1912) - det synspunkt, at mennesket er kendetegnet ved en 'uundgåelig skyldfølelse', en 'urskyld' (Freud 1999, 82, 86). Han giver imidlertid forskellige forklaringer på, hvorfra denne skyldfølelse stammer. I Totem og tabu er hans forklaring historisk-fylogenetisk, dvs. menneskets 'uundgåelige skyldsfølelse' skyldes en nedarvet, ubevidst erindring om et virkeligt fadermord i en fjern fortid, hvorimod hans forklaring i Kulturens byrde er af biologisk karakter: skyldsfølelsen bunder i en i kulturmennesket fortrængt, men fortsat virksom, medfødt døds- eller aggressionsdrift, der med nødvendighed gør sig gældende i alt levende. ${ }^{10}$

$\mathrm{Nu}$ er dødsdriften jo som nævnt ikke den eneste drift, som ifølge Freud sætter sig igennem i alt levende. Hos den sene Freud anskues mennesket som en slagmark, hvorpå kampen mellem livets to overin-

University Press 1959), samt af nyere dato Merold Westphal, Suspicion \& Faith: The Religious Uses of Modern Atheism (New York: Fordham University Press 1998), 76). Også indenfor psykoanalysen selv er denne lighed blevet noteret bl.a. af Gregory Zilboorg, Mind, Medicine, \& Man (San Diego: Harcourt 1944), 235.

8. Kresten Nordentoft, Kierkegaards psykologi (København: Hans Reitzels Forlag 1972), 266.

9. Sigmund Freud, Totem og tabu (København: Hans Reitzels Forlag 1951), 67; se også Freud (1999, 70).

10. Freuds forskellige forklaringer kan imidlertid udmærket kombineres. Således at man får en biologisk og fylogenetisk model, hvor mordet på urfaderen bunder i sønnernes dødsdrift. Også Freuds ontogenetiske udgave af fadermordsmyten, ødipuskomplekset, kan medtænkes, således at barnets aggression over for faderen føres tilbage til dødsdriften. 
dividuelle og evige modsatrettede kræfter, Eros (livsdriften) og Thanatos (dødsdriften), udspiller sig. Et afgørende spørgsmål bliver derfor, hvilket (styrke)forhold, der består mellem disse to drifter. Freuds svar synes som allerede antydet at være, at dødsdriften på trods af kulturens inddæmningsmekanismer, herunder næstekærlighedsbuddet, i sidste ende altid vil vedblive med at sætte sig igennem; kærligheden formår højest momentvis at aflede dødsdriften ( $\mathrm{fx}$ at vende den indad i overjegets sanktionering af jeget), men aldrig at stoppe eller overvinde den, da den jo netop er et væsenstræk ved livet selv. Endvidere er kærlighed i Freuds optik jo som sagt i sidste ende altid selvkærlighed.

Spørgsmålet om i hvilken forstand - om nogen - det mere præcist teologisk set giver mening at tale om en form for sekulariseret arvesyndslære hos Freud, er for omfattende til, at jeg kan forfølge det videre her. Jeg vil i stedet nøjes med at understrege to for den nærværende sammenhæng væsentlige pointer. For det første, at Freuds kritik af det kristne næstekærlighedsbud samtidig kan være med til at skærpe blikket for den genuint etiske og teologiske indsigt, at der er noget grundlæggende ved menneskets beskaffenhed, der gør, at det aldrig kan leve op til sine egne og omgivelsernes etiske idealer. Kort sagt den samme indsigt, som Kierkegaard formulerer i Begrebet Angest: At etikken strander på synden. ${ }^{11}$ Dette forhold, som er det, jeg forstår som et anti-etisk moment ved næstekærlighedsbuddet, bliver som vi skal se i det næste afsnit tydeligere i Lacans diskussion af Freuds kritik. For det andet, at Freud synes at mangle den horisont på baggrund af hvilken arvesyndslæren forstås i teologien, nemlig frelses- og forsonningslæren. Freud afviser i modsætning til teologien ( $\mathrm{fx}$ Kierkegaard i Kjerlighedens Gjerninger), at evangeliets fordring om at elske næsten kan forandre menneskets grundlæggende kærlighedsdrift eller kærlighedstrang fra selvkærlighed til næstekærlighed. ${ }^{12}$ Derfor ender Freud tilsyneladende i en ensidigt pessimistisk og tragisk livsanskuelse uden det store håb på menneskehedens vegne. For Freud at se, er det kristne næstekærlighedsbud (også) uetisk, fordi det ignorerer eller ligefrem dækker over denne realitet.

11. Søren Kierkegaard, Begrebet Angest Søren Kierkegaards Skrifter 4 (København: Gad 1998), 343.

12. For en uddybende diskussion af forskellen mellem Freud og Kierkegaard på dette punkt, se Kresten Nordentoft, Søren Kierkegaard: Bidrag til kritik af den borgerlige selvoptagethed (København: Dansk Universitets Presse 1977), 168-183. 


\section{Kærlighed til næsten ifølge Lacan}

Freuds måske mest originale og indflydelsesrige arvtager, Jacques Lacan, diskuterer ved flere lejligheder næstekærlighedsbuddet, mest indgående i hans Seminar VII fra 1959-1960 om psykoanalysens etik. Udgangspunktet for Lacans diskussion af næstekærlighedsbuddet i dette seminar er den kritik, som Freud fremsætter af det i Kulturens byrde, og som jeg har skitseret oven for. Det, som Lacan bider mærke i ved denne kritik, er ikke så meget kritikken i sig selv som det forhold, at Freud med sin kritik samtidig afslører, at næstekærlighedsbuddet har en bestemt virkning på ham. Freud er nemlig med Lacans ord "bogstavelig talt skrækslagen" ved buddet, og denne skræk får ham ifølge Lacan til at vige tilbage fra at klarlægge buddets fulde radikalitet. ${ }^{13}$ Formuleret i psykoanalytiske termer er det, der gør Freud skrækslagen, det, at næstekærlighedsbuddet ifølge Lacan appellerer til en særlig lyst, som er hinsides lystprincippet, og som lystprincippet har til formål at inddæmme. En anden måde at udtrykke det på er, at Freud i næstekærlighedsbuddet ser en appel til en form for uhæmmet kærlighed, en excessiv kærlighed hinsides lovens beskyttende grænse, de sociale konventioners utilitarisme og lyst- og realitetsprincippets selvopretholdende logik. Næstekærlighedsbuddet afslører, at denne lyst hinsides lystprincippet, denne uhæmmede kærlighed, er intimt forbundet med en aggressivitet, endda en potentielt selvdestruktiv aggressivitet (dødsdrift), der kendetegner mennesket. Et forhold, der som Freud selv bemærker i Kulturens byrde, kommer til udtryk i situationer, hvor mit medmenneske er parat til at volde mig skade uden hensyntagen til sit eget ve og vel, "hvis han bare kan tilfredsstille en eller anden lyst dermed" (Freud 2010, 60). Lacans betegnelse for denne uhæmmede lyst hinsides lystprincippet er nydelse, jouissance.

I Lacans øjne er det imidlertid netop dette, at næstekærlighedsbuddet konfronterer os med nydelsen og dermed med dødsdriften, der gør det etisk, og som gør det sammenligneligt med det, han forstår som psykoanalysens etik, der er centreret omkring et traumatisk møde med den andens begær. ${ }^{14}$ Men det er samtidig også dette, som bringer såvel næstekærlighedsbuddet som psykoanalysens etik i opposition til store dele af den etiske tradition, hvor det først og frem-

13. Jacques Lacan, The Ethics of Psychoanalysis - The Seminar of Jacques Lacan: Book VII (London: Routlegde 2008), 228

14. Lacan foreslår følgende som marxisme for psykoanalysens etik: "Gå ikke på kompromis med dit begær", hvilket ikke skal forstås som en hedonistisk opfordring til selvrealisering, men som en opfordring til at holde fast ved det ved os selv, der er fremmed for os selv, vores begær, som ifølge Lacan netop altid er "den andens begær" (Lacan 2008, 392, 380). 
mest drejer sig om at udtænke og opstille retningslinjer for realiseringen af det gode eller lykkelige liv. Næstekærlighedsbuddet påbyder os ifølge Lacan ligesom psykoanalysen en traumatisk konfrontation med noget fremmed ved både den anden og os selv; noget fremmed, der undviger vores begreber og problematiserer vores traditionelle opfattelse af godt og ondt, og som derfor i vis forstand kan siges at være anti-etisk. Det teologiske begreb for dette fremmede er som vi skal se hos Kierkegaard netop "Næsten".

\section{Nesten "som ting"}

Spørgsmålet om den overskridelse af lystprincippet og den nydelse, som dødsdriften driver mennesket imod, er et væsentligt anliggende for Lacan i Seminar VII, og særligt i hans diskussion af begrebet das Ding, Tingen, der er hans Freud-inspirerede betegnelse for dette "hinsides lystprincippet", og som han eksplicit forbinder med det jødisk-kristne næstebegreb. Lacan henter begrebet Tingen fra Freuds posthume værk Udkast til en videnskabelig psykologi, som han i første del af Seminar VII præsenterer en læsning af. ${ }^{15}$ I den passage fra Freuds værk, som Lacan refererer, diskuterer Freud erkendelsesprocessen hos et spædbarn. Freud skriver:

Lad os antage, at det objekt, der leverer sansningen, ligner subjektet, et medmenneske. Den teoretiske interesse forklares i så fald også ved, at et sådant objekt på samme tid er det første tilfredsstillelsesobjekt og på længere sigt det første fjendtlige objekt - såvel som den eneste hjælpende magt. I forholdet til medmennesket lærer mennesket derfor at erkende. I så fald vil de sansningskomplekser, der udgår fra dette medmenneske, til dels være nye og usammenlignelige, dets træk, fx på det visuelle område; andre visuelle sansninger, $\mathrm{fx}$ af dets håndbevægelser, vil imidlertid i subjektet falde sammen med erindringen af egne, ganske lignende visuelle indtryk af den egne krop, med hvilke erindringerne om selvoplevelse bevægelser er associerede. Atter andre sansninger af objektet, $f_{x}$ når det skriger, vil vække erindringen om egen skrigen og dermed egne smerteoplevelser. Og således spalter medmenneskets kompleks sig i to bestanddele, hvoraf den ene imponerer ved konstant struktur, $[\mathrm{og}]$ holder sammen som ting, medens den anden kan forstås

15. Som flere kommentatorer påpeger, trækker Lacan også på overvejelser over dette begreb i en bredere filosofisk tradition fra Kant til Heidegger. Se fx Simon Critchley "Das Ding: Lacan and Levinas", Research in Phenomenology 28 (1998), 72; Marc de Kesel, Eros \& Ethics: A Reading of Jacques Lacan's Seminar VII (New York: Suny 2009), 83. 
gennem erindringsarbejde, dvs. tilbageføres til efterretninger fra den egne krop. ${ }^{16}$

Lacan knytter an til flere pointer i denne passage. Først og fremmest bider han mærke i, at der i erkendelsesprocessen ifølge Freud altid er et element ved medmennesket, som undslår sig subjektets perception af dette, nemlig det element, Freud benævner als Ding. Tingen er det ved medmennesket eller næsten, der ikke lader sig bestemme gennem subjektets sammenligning med sig selv, det som ikke lader sig reducere til det erkendende subjekts egne repræsentationer af næsten. Det vil sige, at Tingen er det usammenlignelige ved næsten, der gør, at han eller hun ikke lader sig restløst erkende. Tingen er den reelle rest, der unddrager sig i subjektets imaginære og symbolske identifikation af næsten, og som gør næsten til noget fremmed for subjektet. ${ }^{17}$ Eller med Lacans ord: "Das Ding er det element som fra starten isoleres af subjektet i hans erfaring af der Nebenmensch som værende i kraft af selve dets natur fremmed, Fremde" (Lacan 2008, 62) Dette element ved næsten, Tingen, har ifølge Lacan ikke kun betydning i perceptionsrelationer men også i kærlighedsrelationer, hvilket også antydes i Freuds karakteristik af medmennesket eller næsten som det første tilfredsstillelsesobjekt, det første fjendtlige objekt og den første hjælpende magt (Lacan 2008, 46-47).

Det er altså ifølge Lacan medmenneskets karakter af Ting, der gør det fremmed, ja endda til en absolut anden, i forholdet til subjektet (Lacan 2008, 62-63). Men Tingen betegner for Lacan ikke kun det, der gør den anden fremmed for subjektet; Tingen betegner ligeledes det, der gør subjektet fremmed for sig selv, og derfor kan Lacan også hævde, at selvom, at Tingen er noget fremmed ved anden, er den samtidig noget fremmed i hjertet af subjektet selv (Lacan 2008, 8788). Den fremmedhed, som Tingen betegner, er på den måde på én og samme tid helt tæt på og absolut anderledes end subjektet. Tingen er, som Lacan skriver, et "intimt eksteriør", eller med hans egen neologisme: Tingen er ekstim (fr. extimité) (Lacan 2008, 171). Man kan også sige det på den måde, at Tingen udgør noget umenneskeligt ved mennesket i den forstand, at Tingen betegner dét særlige ved mennesket, som definerer mennesket, men samtidig unddrager sig mennesket. Eller som Lacan formulerer det: "Tingen [...] definerer den menneskelige faktor - selvom den menneskelige faktor som bekendt

16. Sigmund Freud, Udkast til en videnskabelig psykologi (København: Hans Reitzels Forlag 1980), 79.

17. For en kortfattet præsentation af Lacans tre ordner, se Jacques Lacan, "Det symbolske, det imaginære og det reelle", Almen semiotik 5 (1992), 8-24. 
undviger os" (Lacan 2008, 154). ${ }^{18}$ Det, subjektet og næsten har til fælles som mennesker, er således ikke en bestemt identitet, men snarere en mangel på en bestemt identitet.

I mødet med medmennesket konfronteres subjektet som allerede antydet ikke kun med den andens fremmedhed, men også med sin egen fremmedhed, ikke kun med den anden som Ting, men også med sig selv som Ting. Medmenneskets tingslige karakter konfronterer subjektet med, at han ikke ved, hvad det er, medmennesket vil have af ham, hvad medmenneskets begær er, men også, at han ikke ved, hvad han vil have, at medmennesket skal gøre for ham, altså at han heller ikke kender sit eget begær. ${ }^{19}$ Tingen er det ved den anden, ved medmennesket, som unddrager sig subjektets narcissistiske identifikation og det, der konfronterer subjektet med, at der også er noget ved det selv, som unddrager sig dets narcissisme, og som derfor gør det muligt for det at sætte sig udover dets narcissisme. Mødet med næsten bliver således 'uhyggeligt' i Freuds særlige forståelse af termen (dvs. det udgør en form af det fortrængtes tilbagevenden), fordi subjektet gennem konfrontationen med medmenneskets mangel, påmindes om dets egen mangel. Derfor er forholdet til medmennesket, mødet med næsten, ifølge Lacan også af altafgørende betydning for subjektets selvforhold (2008, 47). Med Slavoj Zižeks ord:

Men for Freud og Lacan (som det er overbevisende uddybet af Jean Laplanche) er det traumatiske møde med den anden som en begærende [Ting], der 'bryder ind i det narcissistiske kredsløb', netop den grundlæggende erfaring, som er konstituerende for den begærende subjektivitet - hvilket er grunden til, at begær for Lacan er 'den andens begær'. ${ }^{20}$

I den engelske filosof Simon Critchleys læsning af Lacan bliver mødet med næsten endvidere udlagt som betingelsen for det etiske subjekts indstiftelse $\mathrm{i}$ den forstand, at det først er gennem påmindelsen om dets egen andethed $i$ en traumatisk konfrontation med næstens andethed, at subjektet kan åbne sig for næstens andethed. ${ }^{21}$

18. Vedrørende det umenneskelige ved næsten som Ting, se også Slavoj Žižek, "Neighbors and Other Monsters", i The Neighbor: Three Inquiries in Political, red. Slavoj Žižek m.fl. (Chicago: University of Chicago Press 2005), 162-165.

19. Subjektet 'als ding' er ifølge Lacan altså kort sagt begærsubjektet: "Begærsubjektet [...] er intet andet end Tingen, som i sig selv er det, der er tættest på ham samtidig med, at det undslipper ham mere end noget." Jacques Lacan, Écrits. (New York: W \&W Norton Publishing 2006), 549-550.

20. Slavoj Žižek, Less than Nothing: Hegel and the Shadow of Dialectical Materialism (London: Verso 2012), 828.

21. Simon Critchley, "Das Ding: Lacan and Levinas", i Research in Phenomeno$\log y 28$ (1998), 84. 
Men som det fremgår af Lacans diskussion i Seminar VII er mødet med næsten som Ting langt fra uproblematisk (Lacan 2008, 238). Som regel er mødet med næsten som Ting en konfrontation med en anmassende anden, der invaderer vores personsfære med sine underlige lyster og som derfor ofte udløser en følelse af irritation, frygt eller ligefrem aggressivitet i os. Eller som Žižek formulerer det:

Da næsten, som Freud anede for længe siden, først og fremmest er en ting, en traumatisk ubuden gæst, en person, hvis anderledes livsstil (eller rettere anderledes måde at udleve sin jouissance på) forstyrrer os, skubber vores liv ud af balance, afsporer det, kan det, når næsten kommer for tæt på, også give anledning til en aggressiv reaktion, der har til formål at komme af med denne foruroligende, ubudne gæst. ${ }^{22}$

Den aggressivitet, som frygten for næstens nydelse fremkalder, implicerer ifølge Lacan imidlertid også nydelse hos os selv, nemlig den nydelse, der er forbundet med at (kunne) berøve næsten hans underlige lyster, hans nydelse $(2008,229)$.

Grunden til, at Freud ifølge Lacan er skrækslagen over næstekærlighedsbuddet er jo som sagt netop, at det rejser spørgsmålet om menneskets nydelse (jouissance), om den smertefulde, ja i sidste ende potentielt dødbringende, lystfølelse, der er forbundet med at forfølge sine underlige lyster hinsides lystprincippet (Lacan 2008, 231 og 239). Som Lacan på provokerende vis pointerer i sin genfortælling i Seminar VII af helgenlegenden om Saint Martin, der næstekærligt giver sin kappe til en tigger: hvad nu, hvis tiggerens ønske om næstekærlighed slet ikke bestod i, at Saint Martin skulle give ham sin kappe, men i at Saint Martin skulle udnytte ham seksuelt eller slå ham ihjel. Ved næstekærligt at tilbyde tiggeren sin kappe, dvs. ved at tilbyde tiggeren det, som Saint Martin selv anser for et gode, beskytter han sig imod ikke kun næstens, men ligeledes sin egen nydelse (Lacan 2008, 229).

Lacans kritiske pointe er altså, at næstekærlighedsbuddet - hvis det udlægges med en på forhånd fastlagt definition af hvad kærlighed og næsten er - kan komme til at fungere som en forsvarsmekanisme imod næstens fremmedhed, hans nydelse, og er dermed i Lacans forstand uetisk. Det betyder ikke, at Lacan mener, at sand næstekærlighed så består i at udnytte eller dræbe næsten, hvis det er det, næsten forestiller sig vil bibringe ham eller hende nydelse. Næstekærlighed består ikke $\mathrm{i}$ at give det, man selv eller næsten tror, han eller hun vil nyde at få, hvad enten det er en kappe eller døden (begge dele ville i

22. Slavoj Žižek, Violence (London: Profile Books 2008), 50. Se Lacan (2008), 239. 
en vis forstand være uetisk), men $\mathrm{i}$ at konfrontere sig med næstens og sin egen nydelse. En sådan konfrontation kunne måske etableres ved i stedet "at give det man ikke har til én, som ikke vil vide af det", som en af Lacans definitioner af kærlighed lyder. ${ }^{23}$ Altså en kærlighed, der afstår fra blot at bekræfte såvel vores egen som næstens identitet. En opfattelse af næstekærlighed, der rummer et sådan begreb om næsten, altså som noget, der stille spørgsmålstegn ved såvel vores egen som den andens identitet, finder man hos Kierkegaard.

\section{Næstebegrebet hos Kierkegaard}

Kjerlighedens Gjerninger, der kan læses som en lang meditation over næstekærlighedsbuddet, rummer Kierkegaards mest omfattende behandling af næstebegrebet. Kierkegaard diskuterer eksplicit spørgsmålet om, hvorledes man skal forstå begrebet naste i afsnit II. B. med titlen Du skal elske "Nesten" i bogens første del. Men allerede i de foregående afsnit har han fremsat flere væsentlige betragtninger over begrebet. I en central passage i afsnit II. A. skriver han således:

Hvo er da Ens Næste? Ordet er aabenbart dannet af Nærmeste, altsaa er Næsten Den, der er Dig nærmere end alle Andre, dog ikke i Forkjerlighedens Forstand, thi at elske Den, der i Forkjerlighedens Forstand er En nærmere end alle Andre, er Selvkjerlighed - "gjøre ikke ogsaa Hedningerne det Samme?” Næsten er da Dig nærmere end alle Andre. Men er han Dig ogsaa nærmere end Du er Dig selv? Nei, det er han ikke, men han er just, eller han skal just være Dig lige saa nær. Begrebet "Næste" er egentligen Fordoblelsen af Dit eget Selv; "Næsten” er hvad Tænkerne vilde kalde det Andet, Det, hvorpaa det Selviske i Selvkjerligheden skal prøves. ${ }^{24}$

Næstens ambivalente karakter af nærhed og fremmedhed (eller med Lacan, næstens "ekstimitet") træder tydeligt frem i dette citat. Næsten er ifølge Kierkegaard på den ene side "Den, der er Dig nærmere end alle Andre" og på den anden side "hvad Tænkerne vilde kalde det Andet." Altså både tæt på og andet end. Og Kierkegaard uddyber disse udsagn om nærhed og andethed yderligere. For det første præci-

23. Jacques Lacan, Problèmes cruciaux pour la psychoanalyse: Séminaire XII 19641965. Citeret fra Kirsten Hyldgaard, Fantasien til afmagten: syv kapitler om Lacan og filosofien (København: Museum Tusculanum 1999), 115.

24. Søren Kierkegaard, Kjerlighedens Gjerninger, Søren Kierkegaards Skrifter 9 (København: Gad 2004), 28-29. 
serer han, at den nærhed mellem den enkelte og næsten, som han taler om, ikke skal forstås som en nærhed "i Forkjerlighedens Forstand", da den nærhed, vi føler til den anden i forkærligheden i sidste instans, er udtryk for selvkærlighed og dermed i virkeligheden en nærhed til os selv. Formuleret på en anden måde: i forkærligheden er den særlige, udvalgte anden (den elskede eller vennen) os nær, fordi vi kan identificere os med hende og spejle os i hende, dvs. fordi vi finder, at hun ligner os selv. I forkærligheden er næsten os nær, fordi hun gøres til et spejlbillede af os selv eller med Kierkegaards ord til "det andet jeg". Men som Kierkegaard understreger: "Enten vi tale om det første Jeg eller om det andet Jeg, dermed ere vi ikke komne Næsten et Skridt nærmere; thi Næsten er det første Du" (Kierkegaad 2004, 64). Hvis næsten skal være noget andet end jeget, må det være noget andet end et andet jeg, da det andet jeg er det samme som det første jeg.

For det andet præciserer Kierkegaard, hvori dette andet ved næsten, som han accentuerer med betegnelsen "det første Du", mere præcist består. Ifølge Kierkegaard er det ikke i kraft af ligheden, at næsten er os nærmere end alle andre - eller mere præcist: ligheden (nærheden) ligger ikke i ligheden, men i andetheden. Kierkegaard benævner godt nok næstens nærhed, som ikke er "i Forkjerlighedens Forstand", for Grund-lighed: "Thi vistnok elskes Hustruen anderledes end Vennen, og Vennen anderledes end Næsten, men dette er ikke en væsentlig Forskjellighed, thi Grund-Ligheden ligger i Bestemmelsen 'Næsten"' (Kierkegaard 2004, 143). Denne grundlighed består imidlertid ikke $i$, at alle mennesker, når de sammenlignes, har denne eller hin egenskab tilfælles, men i at alle mennesker har dét tilfælles, at de udover det, som kan sammenlignes, også er noget andet, som gør dem usammenlignelige. Den grund-lighed, der "ligger i Bestemmelsen ' $\mathrm{N} x$ sten'”, og som betyder, at næsten er os nærmere end alle andre, dog ikke nærmere os selv end vi selv er, men netop lige så nær, går ikke på det samme, men netop på "hvad Tænkerne vilde kalde det Andet". Det er ikke en bestemt identitet (et bestemt jeg), men en mangel på en bestemt identitet, der udgør den grund-lighed, som næstebegrebet betegner. Det betyder ikke, at ethvert menneske ikke har en bestemt individuel identitet og herved er forskellig fra ethvert andet menneske, der har en bestemt individuel identitet, men det betyder, at intet menneske går restløst op i denne identitet. Ethvert menneske er også noget andet. ${ }^{25}$

25. Som Pia Søltoft bemærker i sin analyse af Kjerlighedens Gjerninger, adskiller den opfattelse af andethed, som Kierkegaards fortolkning af næstebegrebet indebærer, sig fra den opfattelse af andethed, man finder hos Emmanuel Lévinas, ved at Kierkegaard i modsætning til Lévinas fastholder en universalisme i sin etik - ikke som drivkraft for etikken (det er pligtens rolle), men som dens resultat. Pia Søltoft, 
Med næstebegrebet vil kristendommen ifølge Kierkegaard altså på ingen måde afskaffe den forskellighed, der er knyttet til vores særlige identitet, "[...] men den vil, at Forskjelligheden skal hænge løst om den Enkelte [...]". For, som han skriver: "Naar nemlig Forskjelligheden hænger saaledes løst, da skimtes bestandigt i hver Enkelt hiint væsentlige Andet, det for Alle Fælles, det evigt Lignende, Ligningen"(Kierkgaard 2004, 93). Som ordet 'skimtes' antyder, bliver den etik som Kierkegaard skitserer i Kjerlighedens Gjerninger i høj grad en etik, der har at gøre med spørgsmålet om, hvorledes vi ser næsten; en etik, der ikke handler om, at man i sit syn på næsten skal se bort fra forskelligheden, men om at man i sit syn på næsten skal lade forskelligheden "hænge så løst", at det væsentlige andet i næsten bestandigt skimtes. ${ }^{26}$ Det betyder imidlertid ikke, at næstens andethed kan kendes eller erkendes. Tværtimod. Næsten hos Kierkegaard har snarere karakter af Tingen hos Lacan, dvs. næsten udgør noget ukendeligt ved medmennesket: "Næsten er den aldeles ukjendelige Forskellighed mellem Menneske og Menneske, eller den evige Lighed for Gud [...]" (Kierkegaard 2004, 74). Ligesom i Lacans udlægning af legenden om Saint Martin gælder det altså også hos Kierkegaard om ikke på forhånd at bestemme næsten og dermed bestemme sig for, hvad næsten har brug for på baggrund af ens egen eller næstens særegne identitet, men om i stedet at lade denne identitet "hænge løst" og hermed gøre det muligt at konfrontere sig med næstens og sin egen andethed.

Men der er også en afgørende forskel mellem Kierkegaard og Lacan her. For der er mere at sige om det begreb om det andet, som Kierkegaard introducerer i sin analyse af næsten. Når begrebet det andet bringes på bane, rejser det nemlig samtidig et spørgsmål om, hvad dette andet er andet i forhold til. Det andet, som næstebegrebet betegner, er ikke andet i forhold til den anden, altså det andet menneske, for i forholdet til den anden udgør det andet jo netop grund-ligheden, altså det samme. Det andet, som næstebegrebet betegner, er i stedet andet i forhold til den tredje, hvilket for Kierkegaard vil sige Gud: "Christendommen lærer, at Kjerlighed er et Forhold mellem: Menneske- Gud- Menneske, det er, at Gud er Mellembestemmelsen" (Kierkegaard 2004, 118). Kort sagt: I sin andethed over for Gud er ethvert fra hinanden forskelligt menneske lige. Eller med Kierkegaards ord:

"Næsten" er ethvert Menneske; thi ved Forskjelligheden er han ikke

Din Næste, ei heller ved Ligheden med Dig indenfor Forskjelligheden

Svimmelhedens etik: om forholdet mellem den enkelte og den anden hos Buber, Lévinas og iser Kierkegaard (København: Gad 2000), 297.

26. Se Arne Grøn, "Ethics of Vision", i Ethik der Liebe: Studien zu Kierkegaards "Taten der Liebe", red Ingolf U. Dalferth (Tübingen: Mohr Siebeck 2002), 111-122. 
fra andre Mennesker. Ved Ligheden med Dig for Gud er han Din Næste, men denne Lighed har ubetinget ethvert Menneske og har den ubetinget (Kierkegaard 2004, 67).

Også Lacan opererer med en tredjepart i forhold til hvem den andethed, der karakteriserer den anden eller næsten, er andet, og han skelner derfor mellem den lille anden og den store Anden. ${ }^{27}$ Hos Lacan er det ikke Gud, men sproget eller den symbolske orden, som udgør denne tredjepart eller mellembestemmelse (den store Anden). ${ }^{28}$ Sproget er den tredje instans i forhold til hvilken både den ene og anden er andet. Med Kierkegaards terminologi: både det første jeg og det andet jeg har det tilfælles, eller har den grundlighed, at de over for sproget, som mellembestemmelse, er det første du. Det er i forhold til den store Anden (sproget), at det umiddelbare forhold til den (lille) anden (person) brydes, og mennesket bliver noget andet end et (imaginært) andet jeg, nemlig et (symbolsk) subjekt, et første du. Lacan benytter termen 'fadernavnet' (fr. le nom du père) som betegnelse for sproget (den store Anden), og antyder således, at han er ikke uden sans for og kontakt med den teologiske diskurs. ${ }^{29}$

Der er også en anden væsentlig parallel mellem Kierkegaard og psykoanalysen, som understreges af den ovenfor citerede passage, hvor Kierkegaard skriver: "Næsten' er hvad Tænkerne vilde kalde det Andet, Det, hvorpaa det Selviske i Selvkjerligheden skal prøves” (Kierkegaard 2004, 28-29). Næsten er, som denne sætning illustrerer, hos Kierkegaard ligesom i psykoanalysen et begreb om andethed, som er af afgørende betydning for såvel subjektets selvforhold som for dets forhold til den anden, altså etikken i bred forstand, fordi subjektets narcissisme brydes af denne andethed og derved muliggør subjektets åbning imod den anden. Eller med Pia Søltofts ord:

"Næsten" er indbegrebet af den andenhed, som selvet for at blive sig selv må indoptage i selvforholdet, fordi denne andenhed negerer det

27. Jacques Lacan, The Ego in Freud's Theory and in the Technique of Psychoanalysis 1954-1955 - The Seminar of Jacques Lacan: Book II (New York: W \& W Norton Publisher 1991), 235-246.

28. For en uddybning se René Rasmussen, Lacans psykoanalyse: en indforing (København: Hans Reitzels Forlag 1993), 21-24.

29. Jacques Lacan, "Introduktion til Fader-Navnene", i Angst hos Lacan og Kierkegaard - Scrnummer af Drift: Tidsskrift for psykoanalyse, red. René Rasmussen, 9-26. For en uddybning, se Carsten Pallesen, Handlen og varen: Paul Ricoeurs polytetiske refleksionsteori (København: Det Samfundsvidenskabelige Fakultets ReproCenter), 476-480. For en belysning af Lacans forhold til teologien og særligt Kierkegaard, se Marcus Pound, Theology, Psychoanalysis and Trauma (London: SCM 2007). 
selviske i selvkærligheden og åbner dette op for forholdet til det andet menneske" (Søltoft 2000, 284).

Dette andet, som for Kierkegaard udgør en grund-lighed ved ethvert menneske, og som således er definerende for mennesket som sådan, er samtidig qua sin karakter af andethed dét ved mennesket, der gør, at det enkelte menneske aldrig går restløst op i dets bestemmelse som dette eller hint menneske og kan således i en vis forstand godt forstås som et begreb om det (u)menneskelige ved mennesket. Kierkegaard bruger også ordet "umenneskeligt" flere steder i Kjerlighedens Gjerninger, men i betydningen noget ikke-menneskeligt, og altså ikke i betydningen noget (u)menneskeligt ved mennesket. For eksempel skriver han i afsnit II. C:

Selv Den, der ellers ikke er tilbøielig til at prise Gud og Christendommen, han gjør det dog, naar han med Gysen betænker dette Forfærdelige, hvorledes i Hedenskabet Jordlivets Forskjellighed, eller hvorledes Kaste-Inddelingen umenneskeligt skiller Menneske fra Menneske, hvorledes denne Ugudelighed umenneskeligt lærer det ene Menneske at fornegte Slægtskabet med det andet, lærer ham formasteligt og afsindigt at sige om det andet Menneske, at han er ikke til, er "ikke født" (Kierkegaard 2004, 76).

Dette ændrer dog ikke ved, at der i hans begreb om næsten som det andet ligger en opfattelse af, at der er noget ved mennesket, som på den ene side ikke lader sig reducere til noget menneskeligt, og som på den anden side heller ikke blot er en negation af det menneskelige, altså noget ikke-menneskeligt eller dyrisk, men netop er noget (u) menneskeligt ved mennesket.

\section{Afsluttende sammenfatning}

Som jeg har forsøgt at demonstrere i det foregående er det bestemt muligt at etablere en konstruktiv og gensidigt befrugtende dialog mellem teologi og psykoanalyse omkring næstekærlighed, blandt andet gennem en række paralleller mellem Lacan og Kierkegaard. Jeg har med min præsentation af Freuds kritik af det kristne næstekærlighedsbud sigtet på at problematisere samtidens selvfølgeliggjorte tale om næstekærlighed (min første tese), men jeg har også argumenteret for, at Freuds kritik samtidig rummer den genuint etiske og teologiske indsigt, at der er noget grundlæggende ved menneskets beskaf- 
fenhed, der gør, at det aldrig kan leve op til sine egne og omgivelserne etiske idealer (min anden tese). Etikken - i det mindste i en bestemt udformning - strander på synden, på dødsdriften. Det er denne antietiske indsigt, som psykoanalysen til tider selv overser, men som næstekærlighedsbuddets næstebegreb holder os fast på.

Det væsentlige anliggende i min fremstilling har imidlertid været at vise, hvordan næstekærlighedsbuddet og særligt næstebegrebet, hvis det udlægges med afsæt i Lacans og Kierkegaards forståelse af det, ikke kan danne grund for en etik i traditionel forstand, men tværtimod udgør en slags anti-etik, fordi det med dets begreb om næsten fungerer mere som en forhindring for dets egen teoretisering end som en køreplan for det moralske liv eller et filantropisk program (min tredje tese).

Som påpeget flere steder i det foregående, berører Freuds og Lacans betragtninger over næstekærlighedsbuddet et mere generelt spørgsmål om etikkens mulighed og betingelser. For både Freud og Lacan medfører psykoanalysens blotlægning af det menneskelige sjæleliv en kritisk indstilling til etikken, som hos Freud paradigmatisk kommer til udtryk i hans moralgenealogiske afsløring af, at filosofiens højagtede morallov ( $f_{x}$ Kants kategoriske imperativ) i virkeligheden intet andet er end det overjeg, der er blevet til gennem ødipuskompleksets internalisering af de gældende samfundsnormer. ${ }^{30}$ Etikken er i en vis forstand for både Freud og Lacan blot et (givetvis nyttigt) ideologisk redskab til tugtelsen og fiksering af menneskets begær (Freud 1999, 92-94; Lacan 2008, 386). Som jeg har understreget, kan man imidlertid sige, at denne kritiske attitude til etikken samtidig også i sig selv udgør et etisk moment. Desuden er såvel Freud som Lacan naturligvis klar over, at psykoanalysen, og særligt den terapeutiske del, involverer centrale etiske problemstillinger, og at den derfor ikke kommer udenom en etisk stillingtagen, hvad der bl.a. kommer til udtryk i, at Freud rent faktisk opstiller et klart mål for den psykoanalytiske behandling udtrykt i hans berømte maksime: "wo es war soll ich werden." ${ }^{11}$ Psykoanalysen rummer dermed både en etikkritik eller anti-etik, men også en anden form for en etik, der viser sig på baggrund af denne kritik. ${ }^{32}$

30. Se fx Sigmund Freud, "Jeget og det'et" i Freud (1976), 189.

31. Sigmund Freud, Nye forelasninger (København: Hans Reitzels Forlag 1983), 67. Udlægning af denne maksime er et stærkt omdiskuteret emne i psykoanalysen. For Lacans fortolkning, se Lacan, Écrits (2006), 345-348.

32. Noget lignende kan siges at gøre sig gældende hos Kierkegaard. Se Arne Grøn, “Anden” etik” i Studier i Stadier. Søren Kierkegaard Selskabets 50-års Jubilaum (København: Hans Reitzel 1998), 75-87. 
Jeg har fokuseret på Lacan, der som nævnt i høj grad udvikler sin position i Seminar VII og i tæt diskussion med næstekærlighedsbuddet. Såvel Lacans 'etik' som næstekærlighedsbuddet har i modsætning til store dele af den etiske tradition ikke tæmningen eller inddæmningen af vores begær som sit mål. Målet er her, som jeg har forsøgt at argumentere for i denne artikel, snarere en konfrontation med vores begær og nydelse forstået som det, der er det andet ved os selv og den anden. Ydermere har jeg påpeget, at Lacans etik og næstekærlighedsbuddet også har det til fælles, at de ikke udsteder konkrete handlingsregler for, hvordan vi skal omgås dette begær, men netop har til formål at lade den enkelte selv forholde til dette problem.

Næsten - hvis det forstås som et begreb for det andet eller fremmede (Tingen) ved den anden og os selv - udfordrer vores etiske idealer og vores forestilling om en gnidningsløs realisering af disse idealer, og med sin fordring om at elske næsten konfronterer næstekærlighedsbuddet os med den etiske selvsabotage (som Paulus beskriver i Romerbrev 7), med den afsporing af vores gode intentioner, der har sin rod denne fremmedhed. Det er næstekærlighedsbuddets anti-etiske moment: at det udgør en tugtemester, der ved at henvise os til næsten (i den her skitserede betydning) problematiserer vores etiske idealer (dette er måske tydeligst i næstekærlighedsbuddets mest radikale udformning: "Du skal elske dine fjender"). ${ }^{33}$ Men præcis i kraft af accentueringen af næsten som "det fremmede" eller "det andet" bliver buddet $\mathrm{i}$ en anden forstand etisk. Dels fordi det afstår fra konkret at fortælle os, hvem næsten er, eller hvad vi skal og ikke skal gøre, dels fordi det i stedet konfronterer os med et mere fundamentalt spørgsmål om og ansvar for, hvordan vi vil forholde os til det ved den anden og ved os selv, der gør os fremmede ikke bare for hinanden, men også for os selv. I den sidstnævnte betydning er næstekærlighedsbuddets etiske moment nærmere bestemt, at det fordrer af os, at vi i mødet med næsten forholder os til denne fremmedhed, at vi tager den på os og således stiller os åbne for, at det for næsten kan forholde sig på samme måde.

33. For en klar og oplysende diskussion af fjendekærlighedsbuddet som etik kritik, se René Rosfort, "Kritik af forestillingen om et godt liv: Naturalisme, pragmatisme og kristen etik", DTT 76 (2013), 293-295. 